\title{
Colonialism, Collective Memory, and Memory Politics: Critical Reflections on Narratives and Public Archives of the Algerian War
}

\author{
Edad Mercier ${ }^{1}$ \\ ${ }^{1} \mathrm{Ph} . D$. Fellow, Department of World History, St. John's University, New York City, USA
}

\begin{abstract}
ARTICLE INFO
Received: 20 September 2021

Revised: 14 November 2021

Accepted: 15 November 2021

Keywords:

Collective Memory, Public

Memory, Torture, Memoirs,

Colonialism

Corresponding Author:

Edad Mercier

Email:

edad.mercier20@my.stjohns.edu

Copyright (C) 2021, Middle Eastern Journal of Research in Education and Social Sciences.

This work is licensed under the Creative Commons Attribution International License (CC BY 4.0). http://creativecommons.org/licenses/ by/4.0/
\end{abstract}
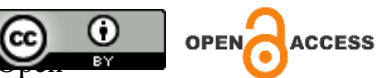

\begin{abstract}
Purpose: The article examines the trial of French General Paul Aussaresses ( $b$. 1918, d. 2013) in the 2000s for war crimes committed during the Algerian War (1954 to 1962).

Approach/Methodology/Design: A historiographical analysis covering topics such as colonialism, public memory, collective memory, counter-narratives, education, forgetting, and authenticity.

Findings: Public history without individual memories or lived experiences of communities that have survived historical events can be viewed as inauthentic. It might even be called propaganda to present only state-sanctioned accounts of historical events. Many governments will consequently enact laws to distinguish between what constitutes official national narratives-and what remains peripheral, or perhaps extremist individual, historical accounts.

Practical Implications: This paper contributes to the scholarly literature examining oral testimonials in political and war crime tribunals, and the ethics of conducting public history research using media archives.

Originality/value: Towards a greater understanding of collective memory processes, the case of the Algerian War reveals the constant negotiations, formal networks, and informal channels used to distinguish between legitimate and illegitimate sources of historical memory-and the consequences on culture, law, and society.
\end{abstract}

\section{INTRODUCTION}

Collective memory influences political action, individual behavior, and social group identity formation. Examining the politics of collective memory building within governments, regimes, and non-state entities, reveals the formal and informal roles that individuals play in determining what constitutes transposable and incompatible memory cultures. Collective memory in historical studies is studied in relation to the saliency of events, such as World War II. Bourdieu's ethnomethodological framework for studying social reproduction also inspires greater reflection on the practice of collective memory building, whether it be at sites of remembrance or during ritual events. In this paper, I argue that the process of collective memory making is guided by disparate beliefs about authentic historical "truths", individual and group 
claims to specific ethno-political identities, and government investments in future political narratives. The Algerian War and its representation in French media, taken as a case study, manifests the tension inherent in distinct and opposing conceptualizations of what constitutes permissible collective memories, produced by state and non-state actors.

On September 17, 2021, international news outlets reported on the passing of former President of Algeria, Abdelaziz Bouteflika. Bouteflika was an influential political and military leader, having joined the National Liberation Front (FLN) during the Algerian War. On Bouteflika's passing, French President Emannuel Macron released a statement from l'Elysée calling the former Algerian President a "major figure" and "an important partner for France."1

Known for his proposal entitled the Charter for Peace and National Reconciliation, drafted in response to the Algerian Civil War (1991 to 2002), Bouteflika argued for a "new" Algeria based on peace, justice, and accountability. Yet, the path towards harmony and stability remained fraught with political, economic, and cultural conflicts in Algeria and abroad. "Culture wars" and legal disputes, especially concerning the broader legacy of French colonialism in Algeria, unfolded before the public well into the $21^{\text {st }}$ century. One example is the Aussaresses scandal.

In 2000, French Army general Paul Aussaresses publicly denied any culpability for his involvement in the Algerian War, which incensed some politicians, journalists, and human rights activists globally. Aussaresses was accused of being an apologist for war crimes, issued a summons, and fined. Aussaresses was not the only public figure to publish his version of the war. There were other accounts from activists, such as Algerian writer Louisette Ighilahriz and French-Algerian journalist Henri Alleg, that revealed the racialization of Islam during the colonial era, controversial reeducation campaigns of Algerian combatants, and African women's roles in colonial resistance. Yet, in later years, Aussaresses, speaking as a retired French army official, received the most media attention-with the scandal ultimately revealing the challenge of preserving oral histories and collective biographies on French colonialism in Algeria, while maintaining national peace, diplomatic ties, and freedom of speech.

Official state discourses in France and Algeria, recognizing the Algerian War, which clashed with Aussaresses's moralization of the war, also concretized a larger political, cultural, and social dilemma-how to discuss historical traumas in classroom education and integrate individual memories within public commemorative project designs without reviving cultural nationalist sentiments glorifying colonial historical pasts framed as authentic historical "truths"?

\section{Collective Memory And Historical Pasts}

Collective memory refers to the shared experiences, knowledge, and narratives that form a group identity or sense of group belonging. French sociologist Maurice Halbwachs advanced the concept of collective memory in Les cadres sociaux de la mémoire (1925) where he argued that memories of a shared past existed outside of individual memories and formed the basis of group consciousness. The effects of acculturation for example are studied through collective cultural memory or memory reports (SJ Schwartz et al., 2010).

\footnotetext{
1 “Abdelaziz Bouteflika a été inhumé à Alger, Emmanuel Macron salue une « figure majeure » de l'Algérie," Le Monde, September 19, 2021.
} 
Building off Halbwach's research on collective memories that connect people to a cultural heritage, Assmann identified three types of memory: individual, communicative, and cultural memory. According to Assmann, communicative memory "is noninstitutional...it lives in everyday interaction and communication and, for this very reason, has only a limited time depth which normally reaches no farther back than eighty years, the time span of three interacting generations" (Assmann, 2008, 111). Assmann also maintained that "communicative genres" frame how communicative memories are passed along between generations. "Traditions of communication" for example build a sense of community social cohesion through "affective ties that bind together families, groups, and generations" (Assmann, 2008, 111). Cultural memory however is "exteriorized, objectified, and stored away in symbolic forms" through cultural heritage sites, museums, and cultural foundations (Assmann, 2008, 110). On the "materialization of memory," Pierre Nora argued that archiving was a way to commemorate and represent cultural memories in forms viewable to the public.

Oral historians specialize in conducting historical research through recorded interviews and narratives. The purpose of these interviews is to collect, store, and organize individual, cultural, or community memories. Oral history research can serve as a window into the histories of marginalized groups. Additionally, oral histories function as testimonials in judicial tribunals, such as the International Criminal Tribunal for Rwanda and the International Criminal Tribunal for the former Yugoslavia (ICTY), where oral testimonials from victims helped courts prosecute war crimes and perpetrators.

Aimé Césaire's lecture on "Culture and Colonization" in $1956^{2}$ revendicated the idea that African civilizations and oral histories should be part of the larger lexicon on world cultures and histories. Decolonization movements during the twentieth century that toppled despotic regimes of colonial authoritarian rule, and weakened European and American influence in Africa, Asia, and Latin America, espoused the concept of a worldview rooted in restorative justice and cultural remembrance projects through literary and artistic forms, such as poetry, storytelling, and speech.

Oral history research is a subjective methodology however, where individual or inter- intragroup bias, from the researcher(s) or narrator(s) can occasionally impede interview collection. Critics of African nationalism and négritude for instance have argued that its founders romanticized the past and essentialized the experiences of the African Diaspora. Romanticization, misrepresentation, or sensationalization of the past and cultural memory in oral history research has occasionally led to generalizing terms like "traditional memory" and "indigenous memory cultures" - which downplay the role of official state actors in actual memory making processes. State actors play a forceful, sometimes violent role, in determining national memory and discourse, which impact individual recollections or reluctance to divulge information about personal or collective lived experiences.

\footnotetext{
${ }^{2}$ Aimé Césaire delivered his speech "Culture and Colonization" at Le Premier Congrès International des Ecrivains et Artistes Noirs, a conference on postcolonial thought and practice, organized by intellectuals and activists in partnership with the journal Présence Africaine in Paris in 1956.
} 
Frantz Fanon's chapter "On Violence” in The Wretched of the Earth is a radical critical inquiry into the colonizer-colonized dialectic on oppression, racism, brutality, dehumanization, justice, and human agency during the colonial era and decolonization period. Fanon argued that the struggle for Algerian independence was an example of revolt against the intimidation tactics of colonizers, who engaged in both psychological and physical warfare with North Africans. Fanon framed two types of intellectuals during the colonial era-the colonized intellectual and the colonizer intellectual. The role of the colonized intellectual was threefold: 1) to regain a sense of intellectual agency after having been dispossessed; 2) to avoid the trap of behaving "like a vulgar opportunist" by overidentifying with or essentializing the conditions of the colonized masses; and 3) to critique the debased conditions of the colonized world without living in a constant "state of rage" or assimilating (Fanon, 1963, 13; 17; 22).

For Fanon, the role of the colonizer intellectual was to condition a total adherence to the colonial world by producing propaganda to establish the inferiority of the colonized and train the "colonial subject...to remain in his place and not overstep its limits" (Fanon, 1963, 15). The colonizer intellectual's main occupation was to justify the existence of occupying forces and the colonial subject's place in this system of existence-subsistence. Colonial violence not only changed the physical geographies of occupied spaces, but also marked the cultural memories of the people who inhabited occupied territories.

Formal public memory narratives however may intentionally omit such cultural memories and subaltern histories to focus on positive information to reinforce specific community values (Dessi, 2008, 536). This is "consistent with the observation that collective memory is strongly biased towards the suppression of bad signals and rehearsal of good signals in totalitarian regimes" (Dessi, 2008, 536). Regime change during the Cold War era that included Soviet occupied East Germany and Allied controlled West Germany, led to modifications in official discourse and commemoration projects to affirm different beliefs about governance and rule (Dessi, 2008, 540). Totalitarian regimes may also over-invest in positive information leading to increased skepticism among younger people about information from official government sources (Dessi, 2008, 540).

\section{Public Education And Collective Memory in Europe}

Media, education, and commemoration sites are central in the process of memory suppression, memory creation, and shared memory cultures. In multicultural societies with competing cultural memories or counter-narratives that play out in the press "...each group provides 'checks and balances' that limit the scope for other groups to transmit their preferred version of the past" (Dessi, 2008, 537). Ultimately, "welfare-enhancing manipulation of memory" is reduced with cultural heterogeneity: "a bad signal for one community's culture, which might have been worth suppressing from the perspective of that community, is no longer worth suppressing if it also represents a good signal for the other community's culture" (Dessi, 2008, $553)$.

In From Museum to memory institution: the politics of European culture online Elizabeth Stainforth argued that the way memories are interpreted by diverse communities is linked with how they are stored: "Memory is indicative of a conceptual investment; on the one hand, in how 
the cultural past is experienced collectively, on the other in a mode of organization or storage" (Stainforth, 2017, 328). Memory "storage" is structured by relationships and increasingly digital networks. The European Commission's "uptake of collective memory in cultural heritage projects is intimately linked to its wider efforts to forge and popularize a cohesive European identity (Shore 2006: p.8; Stainforth, 2017, 326).

In 2005 when Google Books announced its plan to start digitizing cultural materials and resources, the European Commission (EC) became concerned that cultural information from within the European Union would be transmitted to the private sector (Stainforth, 2017, 328). Consequently, the EC began focusing on digitizing collective memory projects. The EC's decision to create a "memorial culture" represents a "geo-political entity aspiring toward a supranational, trans-national identity," where networked memory cultures can interact with each other (Stainforth, 2017, 333).

One example of an EC digitization project is Europeana 1914-1918, a commemoration project for the First World War Centenary. The project uses the Europeana database - online content aggregated from national collections, several European roadshows, private manuscripts and memorabilia from the war, personal stories, and images (Stainforth, 2017, p.12). The goal is to create a site of commemoration for WWI that has readily available and adaptable content (Stainforth, 2017, 331-2).

Education systems as political and narrative-shaping spaces are also active in the construction and deconstruction of national narratives and public memory on 'villains' 'victors' and 'heroes,' particularly during and after periods of military conflict. The transmission of knowledge within education systems is both explicit and implicit - that is the teacher overtly exercises his or her pedagogical duties to a class (grading exams, assigning homework, attendance etc.); while also exercising "value-imposing operations" (reciting the national anthem, etc.) as directed by the school or university leadership. Bourdieu (1984) also maintained that systems of formal education become the repositories for determining legitimate, illegitimate, and transposable cultures.

Consequently, a hierarchy of education spaces and cultural memories is said to exist - or a double geography, where "some places are valorized as canonical or exotic, as exemplary sites of consuming interest, whereas others are marginalized as merely other, less interesting or less instructive instances of more general conditions that are better exemplified elsewhere" (Heffernan and Jöns, 2013, 8).

In the 1990s international organizations began classifying education assistance as a humanitarian issue - noting the ways it can serve humanitarian and social cohesion goals, such as promoting reconciliation and creating safe spaces for displaced persons and public commemoration projects. The Inter-Agency Network for Education in Emergencies (INEE) includes over 500 non-governmental organizations, educational and research institutions, bilateral and multi-national agencies. The steering group of the INEE is led by several agencies such as UNESCO, UNICEF, UNHCR, Norwegian Refugee Council (NRC), CARE and Save the Children. 
A report from the International Bureau of Education (IBE)/University of Geneva on the role of schools during the nation-building process offered insights into how schools represent a convergence of sociocultural memory and political values (Tawil, 1997?, 9):

Schooling may either work toward a set of common values among different national communities, or toward reaching an understanding and acceptance of a plurality of interpretations. Schooling then, is clearly an instrument of integration in the process of nation-state building, and may be conflictual in a situation of multicultural societies.

During emergency resettlement crises, the IBE proposes a rapid educational response that promotes acculturation through citizenship and cultural heritage projects: "The main principle is that children should quickly be brought together in group educational activities led by refugee teachers using the same language of instruction and core curriculum of the country or region of origin" (Tawil, 1997?, 11).

Researchers from the Northern Ireland Community Relations Council found that historical memory pertaining to ethno-religious (Protestant, Catholic) symbols, conflicts, and identities was primarily diffused through the family, local community, and school. These factors appeared to increase children's awareness and attitudes on ethno-religious groups, colors, and symbols: "From the age of three, Catholic and Protestant children were found to show small but significant differences in their preferences for particular people's names, flags and in terms of their attitudes towards Orange marches and the police" (Connolly et al., 2002, 5). The idea then is that peace education curricula will promote intercultural dialogue between younger generations by helping to build skills in problem solving, social-emotional and attitudinal learning, all while reinforcing national peacebuilding narratives.

\section{Public Education in France, Collective Memory, And the Algerian War}

French colonialism in Algeria from 1830 to 1962 encompassed several distinct stages. Under the second Republic, Algeria was part of France. French peasants, working class individuals, and criminal deportees were encouraged to settle the rural areas in Algeria that were occupied by authorities. The white settlers in Algeria were known as pieds-noirs. The question of how to incorporate the existing Algerian Muslim population into the French Republic became a critical issue for French officials. Although Algeria was "part of France" by royal decree, full French citizenship was not immediately granted to Algerians.

The French Republic issued a second decree in 1865 which stated that Algerians could serve in the French armed forces, move to France, and be conferred some protections under French law. However, to become full legal citizens Algerians must accept the French legal code. This meant rejecting religious courts, which Muslim Algerians refused to do. By the early to mid-twentieth century, Algeria's wealth and industry were controlled by European settler pieds-noirs, and Algerians were left out of political decision making. Barred from most administrative posts, due to rules surrounding elections, religious courts, and voting in civil communes, Algerians held few positions of influence in the Algerian National Assembly. 
The Front de Libération Nationale or FLN (National Liberation Front), formed in 1954, was an umbrella organization comprised of several revolutionary bodies. Guiding ideologies of the FLN included staunch Algerian state and Arab nationalism. The FLN employed guerrilla urban warfare tactics, terrorism against civilians and torture to disrupt French occupation in Algeria and encourage Algerian patriotism and solidarity. The FLN movement was not exclusive to socalled "agitators" but rather a greater call for Algerian unity in resisting French rule. The French military responded to the FLN by instituting a series of military "pacification" campaigns that included torture and executions.

Pacification campaigns involved intelligence operations to gather information about the structure of the FLN and its branches. Other tactics included recruiting and training HarkisMuslim Algerian French auxiliary soldiers - to fight with occupying French forces and eventually infiltrate the FLN. Researchers estimate that there were 250,000 Algerian auxiliaries, 50,000 professional soldiers, 120,000 volunteers and 30,000 officials during the Algerian War. One French soldier's letter, as referenced in Horne's A Savage War of Peace: Algeria, 19541962, recounted administering torture during the war: "They used to ask for volunteers to finish off the guys who had been tortured (there are no marks left that way and so no danger of a witch hunt later)...The whole thing revolted me. I fired...After that it wasn't so bad" (Horne, 2006, 233).

Some French generals resigned from their posts because of the rampant use of torture. General Jacques de Bollardière and Secretary-General Paul Teitgen, for instance, resigned in protest. In an interview Bollardière stated that the official orders to torture during the Algerian war were "in absolute opposition to the respect of man...if the leadership yielded on the absolute principle of respect for human beings...it meant an unleashable of deplorable instincts" (Horne, 2006, 203). Teitgen, who was tortured under the Gestapo, also sent in his letter of resignation after concluding that the use of torture during the Algerian War was reprehensible and illegal (Horne, 2006, 203-4). Nevertheless, the use of torture continued throughout the war.

By the end of the Algerian War in 1962 with the Evian Accords, a ceasefire agreement-an estimated 2 million people were killed, nearly 850,000 mostly affluent pieds-noirs moved back to France and slightly less than 30,000 Harkis had resettled in mainland France. The legacies of the war were threefold: (1) A surge in the pieds-noirs population in Southern France (in cities like Nice and Lyon); (2) a turn in the public discourse on the war from one of denial to state-led propaganda on wartime activities; and (3) urban unrest (protests, riots) in metropolitan France.

The cumulative effect of these changes was a significant shift in the tone and administration of the education system in France. More than four decades would pass before the term "Algerian War" became part of the official public record and national commemorative projects in France. Historian Jean-Pierre Rioux, author of La Guerre d'Algérie et les Français argued that the Algerian War was a disturbing part of French history that public officials preferred to forget. According to Rioux, tensions from the war and a national strategy to omit information about the war were most visible in French classrooms- "The republican school in France does not think we should favor the Algerian War to the detriment of other events also so as not to take the risk...of inflaming the memory conflicts that exist and that one can detect in class" (Mccormack, 2006, 143). 
In a survey of French teachers and students, researchers found that teachers were also instructed to provide "less detail" on the Algerian War. One teacher stated, "We [were] asked to insist on long time periods...We should cite the Algerian War only as an example of colonial war" (Mccormack, 2006, 139). Students also remarked that they did not study or discuss the Algerian War in class (Mccormack, 2006, 140). The idea was that memories of the war would fade along with the older generations.

Public censorship and restricted access to wartime archives consequently led to a "very pronounced decrease in the number of words (text) on the Algerian conflict between 1995 and 1998. For example, the textbook published by Nathan had 1,600 words on the war in Algeria in 1995 and 1,000 in 1998. The textbook published by Hatier had 2,800 words in 1995 and 600 in 1998" (Mccormack, 2010, 66).

In his autobiographical book The Question, Henri Alleg, anti-colonialist activist and former editor of the Alger République provided a written history of torture that he endured when he was captured by France's 10 ${ }^{\text {th }}$ Paratrooper Division on June 12, 1957 (Alleg, 2006, 54):

$\mathrm{J}$ - smiling all the time, dangled the clasps at the end of the electrodes before my eyes...He attached one of them to the lobe of my right ear and the other to a finger on the same side... Suddenly, I leapt in my bonds and shouted with all my might. $\mathrm{C}$ - had just sent the first electric charge through my body...C - repeated a single question... 'Where have you been hiding?'

The Question, first published in February 1958, was banned one month later in March 1958 by French authorities because of claims that the book was incendiary and would add to the political and military violence. Censorship of The Question in France during the Algerian War follows a longer colonial history of archival restrictions and nationalist propaganda.

In "Seeing the Empire Through Lists and Charts: French Colonial Records in the Eighteenth Century" Marie Houllemare argued that "imperial" or centralized, national archives give a "biased" view of colonial pasts and historical events (Houllemare, 2018, 391). Concerning the French Bureau de Colonies, created in 1710 by the French Secretariat of the Marine, Houllemare maintained that classification and labeling methods of the ancien régime designed to streamline information about revenue from the colonies, only captured "royal investment in colonies" leaving out the "diversity" of colonies, colonial trade, and colonial experiences (Houllemare, 2018, 390).

Restricted archival access to colonial era events, such as the Algerian War, has further highlighted the challenge of conducting historical research on this period. French historians have pushed back against archival restrictions and censorship with petitions to l'Élysée to declassify documents on intelligence operations during the Algerian War. In solidarity with these efforts, in February 2020, the American Historical Association (AHA) sent a letter to French President Emmanuel Macron "expressing concerns" about restrictions to archives on WWII and the Algerian War. ${ }^{3}$

\footnotetext{
3 “AHA Sends Letter to French President Emmanuel Macron with Concerns about Unclear Procedures for Declassification of Archives (Feb 2020)," American Historical Association.
} 
The "Dispute" ("le contentieux") is perhaps the most demonstrative of the long-standing tensions between preserving historical records and protecting national narratives as they relate to national security interests, which has led to long-term censorship of books and speeches on events like the Algerian War in France (Shepard, 2015, 869-70). The Dispute primarily involved repatriation requests from the Algerian government for the Algerian War archives housed in France during the French colonial period in Algeria. In the 1980s, President Mitterand suggested that France would oversee the return of the Algerian War archives to Algeria. However, President Giscard d'Estaing later disagreed maintaining that the archives were part of France's national heritage (Shepard, 2015, 875-76).

The Dispute reflects how cultural heritage and collective memory projects can exist in multiple spaces, occupied by plural communities, which share distinct and divergent views of the past. Archives-serving-as-institutions further elucidates the importance of deconstructing colonial displays and discourses that suppress the histories and identities of colonized people, while rejecting colonial era archives as the source of absolute historical truths.

\section{"Pour ma part, Je ne Me RePens Pas"4: The Aussaresses Scandal, Individual MEMORY AND LAW}

National narratives on the Algerian War in France are not linear. Rather, disparate and opposing views on what occurred during the war, and strategies for commemorating the war without glorifying colonialism or violence in France have surfaced over decades, leaving historians and archivists with the task of critiquing the Algerian War, as both a colonial conflict and modern rebellion for independence from an imperial power.

Historian Jan Jansen argued that the shift to public recognition of the Algerian War in schools, texts, and public history projects later in the twentieth century was finally the result of "a generational change at the helm of French politics" known as the "génération algérienne" that included "Jacques Chirac, who had participated in the war, and Lionel Jospin, who had opposed it" (Jansen, 2010, 280). On November 11, 1996, Chirac dedicated a monument at the Square de la Butte du Chapeau-Rouge for "victims and combatants killed in North Africa, 1952-62" (Jansen, 2010, 280).

In a speech commemorating the war and war monument, Chirac stated "I do not want to return to either the causes of these often fratricidal confrontations or to the tragedies these battles produced .... That is the reason why we are here, to collect our thoughts, to honour those combatants who gave their lives for France, along with those men and women who died on French soil, soil enriched, for 130 years, by their parents' work" (Jansen, 2010, 281). On June 10, 1999, the French National Assembly approved usage of the expression guerre d'Algérie "Algerian War" in public records instead of the term, opérations which was used prior (Jansen, 2010, 281).

Alongside these remembrance projects and official public recognition ceremonies, individual memories of torture during the war also resurfaced. Journals like Le Monde published a cover

\footnotetext{
${ }^{4}$ Florence Beaugé, "Les aveux du général Aussaresses: 'Je me suis résolu à la torture,"” Le Monde, November 23, 2000.
} 
story in 2000 on Louisette Ighilariz, a writer and member of FLN who was tortured for three months by French soldiers during the Algerian War. Yet, it was revelations made by French Army general Paul Aussaresses, later in 2000, about his role in torture and executions during the Algerian War, that shocked the public and forced French and international officials to take punitive action (Jansen, 2010, 283).

On November $23^{\text {rd }} 2000$, 82-year old General Paul Aussaresses (1918-2013), seized the attention of reporters - not because of the eye patch covering his left eye from injuries sustained in the course of his service during World War II, but from his admission that he participated in around twenty-four summary executions during the Algerian War. ${ }^{5}$ In his interviews, Aussaresses expressed having regrets, but feeling no remorse for having participated in the executions, as these executions were approved by the military.

Aussaresses insisted that the executions were not acts of torture, but the result of a weak French judiciary system with limited capacity to process, imprison, and prosecute individuals deemed dangerous terrorists during the war. ${ }^{6}$ When asked if a soldier should always follow orders, Aussaresses remarked that during the war he was not acting alone, but operating within a hierarchy with rules and expectations. ${ }^{7}$

In another interview with Aussaresses in 2000, prominent Le Monde reporter Florence Beaugé - known for her work on North Africa, human rights, and the torture files from the Algerian War, which implicated members of the Guy Mollet socialist government and François Mitterand ${ }^{8}$ - urged Aussaresses to discuss his role in the Algerian War further. Aussaresses admitted that major military and political leaders during the war were fully aware of torture campaigns - and torture was normalized to the point of being expected from soldiers and generals.

He stated, "La torture ne m'a jamais fait plaisir mais je m'y suis résolu quand je suis arrivé à Alger. A l'époque, elle était déjà généralisée" ["Torture never made me happy, but I decided to do it when I arrived in Algiers. At the time, it was already widespread"]. ${ }^{9}$ The retired general also added: ${ }^{10}$

Si c'était à refaire, ça m'emmerderait, mais je refairais la même chose car je ne crois pas qu'on puisse faire autrement. Pourtant, j'ai le plus souvent obtenu des résultats considérables sans la moindre torture, simplement par le renseignement et la dénonciation. Je dirais même que mes coups les plus réussis, ça a été sans donner une paire de gifles. [If I had to do it again, it would make me angry, but I

\footnotetext{
5 "Général Paul Aussaresses 'les tortures en Algérie"” - Archive video

INA.” Claude Serillon interview with Général Paul Aussaresses, former Intelligence Services Coordinator in Algiers in 1957. (November 23, 2000). Archives of INA Institut National de l'Audiovisuel

6 "Général Paul Aussaresses 'les tortures en Algérie.",

7 "Général Paul Aussaresses 'les tortures en Algérie."”

${ }^{8}$ Beaugé, "Si la France reconnaissait et condamnait ces pratiques, je prendrais cela pour une avancée," Le Monde, November 22, 2000.

${ }^{9}$ Beaugé, "Les aveux du général Aussaresses: 'Je me suis résolu à la torture," Le Monde, November 23, 2000.

${ }^{10}$ Beaugé, "Les aveux du général Aussaresses: 'Je me suis résolu à la torture,"' Le Monde, November 23, 2000.
} 
would do the same thing again because I don't think we could do otherwise. Yet often I achieved tremendous results without the slightest torture, simply through intelligence and denunciation. I would even say that my most successful hits were given without a pair of slaps on the face].

Aussaresses's accounts and insistence that he felt no guilt whatsoever for his service during the Algerian War because he was obeying military orders surprised reporters and politicians. When his memoir on the Algerian War was published in 2001, he was officially condemned.

In his memoir The Battle of the Casbah: Terrorism and Counterterrorism in Algeria, 19551957, ${ }^{11}$ Aussaresses described how upon his arrival in Algeria he was trained on techniques for "extreme interrogation," such as electric shocks or the gégène powered by radio transmitters and water torture (Aussaresses, 2004, 19). He maintained that military commanders at the highest levels were fully aware and condoned the "extreme interrogation" techniques used. He wrote that Interior Minister François Mitterand's de facto representative in Algeria, General Jacques Massu, was aware of and sanctioned torture (Aussaresses, 2004, 128). Aussaresses also detailed one incident where a man, who French authorities suspected was manufacturing bombs, was tortured to death (Aussaresses, 2004, 129-30).

Aussaresses's unapologetic tone in his book and interviews stirred anger within government and media circles. In a May $3^{\text {rd }}, 2001$ article entitled, "L'accablante confession du général Aussaresses sur la torture en Algérie," Aussaresses explained that he published the memoir because: "il y a quelques mois, que la guerre d'Algérie était redevenue d'actualité et qu'elle intéressait beaucoup de monde, je me suis dit que ça valait la peine que je m'explique davantage sur cette période" ["A few months ago, when the Algerian War had become relevant again and that it interested a lot of people, I said to myself that it was worth explaining myself more about this period"]. ${ }^{12}$ Historian Pierre Vidal-Naquet added that such oral and written histories may be important for reconstructing the events and legacy of the Algerian War. ${ }^{13}$

Other editorials like "Crimes de la guerre d'Algérie: divulguer pour ne pas répéter," cautioned that although Aussaresses was recounting his experiences from the war, the entire French army and public memories about the war should not be essentialized because of the individual memories of one man: "L'horreur ressentie à la lecture de certains textes ou des souvenirs du général Aussaresses ne doit pas conduire - et c'est un danger qu'il faut combattre - à une généralisation hâtive qui ferait de l'armée française en Algérie une troupe de tortionnaires" ["The horror felt on reading certain texts or memories of General Aussaresses must not lead and this is a danger that must be fought - to a hasty generalization which would make the French army in Algeria a troop of torturers"]. ${ }^{14}$

On May $4^{\text {th }} 2001$, Le Figaro released several articles that cited various public figures who decried Aussaresses's judgment and character as deplorable: "Le président de l'UDF, François

\footnotetext{
${ }^{11}$ Originally published under the title Services Spéciaux Algérie 1955-1957: Mon Témoignage sur la Torture.

12 Beaugé, “L'accablante confession du général Aussaresses sur la torture en Algérie," Le Monde, May 3, 2001.

${ }^{13}$ Beaugé, "L'accablante confession du général Aussaresses," Le Monde, May 3, 2001.

${ }^{14}$ Georgette Elgey, "Crimes de la guerre d'Algérie: divulguer pour ne pas répéter," Le Monde, May 4, 2001.
} 
Bayrou, a porté hier 'un jugement très dur' sur le livre du général Aussaresses, en jugeant 'abject' le 'sadisme sénile' de l'ancien officier. 'On sait que la guerre, c'est l'horreur"' [“The president of the UDF, François Bayrou, yesterday gave 'a very harsh judgment' on the book of General Aussaresses, deeming the 'senile sadism' of the former officer 'abject.' 'We know that war is horror"']. ${ }^{15}$ Minister of Defense Alain Richard also spoke out against Aussaresses's recollections as the tales of a person whose purported acts of torture were not a product of procedure. $^{16}$

In addition to the national media maelstrom and public horror, international pressure to prosecute Aussaresses mounted. Human Rights Watch authored a letter stating that Aussaresses should stand trial for crimes against humanity - crimes which should not be amnestied. ${ }^{17}$ Excerpts from the letter called upon Chirac "to initiate an urgent, thorough and independent inquiry into allegations by retired General Paul Aussaresses that the French government ordered or tolerated the use of torture and summary executions against supporters of Algerian independence ... in the mid-1950s. Given statements of his own direct involvement, we also call on [Chirac] to initiate criminal proceedings against Gen. Aussaresses."

On May $5^{\text {th }} 2001$, Chirac publicly condemned, "les atrocités, les actes de torture, les exécutions sommaires et les assassinats qui ont pu être commis" ["the atrocities, acts of torture, summary executions and assassinations that may have been committed" ${ }^{19}$ during the Algerian War. He also advised the Minister of Defense to impose military sanctions upon Aussaresses. Aussaresses was stripped of his military rank, his Légion d'Honneur, and the right to wear his uniform. $^{20}$

Under two amnesty laws passed in the 1960s, which barred courts from adjudicating charges related to the Algerian War, and a France war crimes statute which only allowed for war crimes committed during WWII and after 1994 to be tried, ${ }^{21}$ Aussaresses could not be put on trial for war crimes. Additionally, on October $11^{\text {th }}, 2001$, the Laws Commission of the French National Assembly officially refused to create an investigative commission on torture during the Algerian War that various activists had lobbied for. ${ }^{22}$ However, a civil suit, filed by the "Ligue des droits de l'homme" and several other parties, charged that Aussaresses was a war crimes apologist. ${ }^{23}$ Aussaresses was brought before a Paris tribunal - and on January 25, 2002, he was fined 7,500 Euros, and his two publishing houses were fined 15,000 Euros each.

\footnotetext{
15 “Torture en algerie," Le Figaro, May 4, 2001.

16 “Torture en algerie," Le Figaro.

17 "Letter to French President Jacques Chirac Calling for War Crimes Investigation," Human Rights Watch.

18 "Letter to French President Jacques Chirac Calling for War Crimes Investigation."

19 "Chirac veut des sanctions contre Aussaresses," Le Figaro, May 5, 2001.

20 "Chirac veut des sanctions contre Aussaresses," Le Figaro.

21 “Crimes contre l'humanité: le général Aussaresses ne sera pas

poursuivi," Le Monde, December 17, 2001.

22 "Pas de commission d'enquête," Le Figaro, October 11, 2001.

23 “Comment juger nos crimes en Algerie?" Le Monde, May 7, 2001.
} 
Following the Aussaresses condemnation and Paris tribunal decision, journalists continued to play an important role, mediating between official government censure of Aussaresses and public interest in the accounts of the aged military official during one of the most contested wars in French colonial history. An April $5^{\text {th }} 2002$ Le Monde editorial for instance asserted that an important takeaway from the Aussaresses trial should be revisiting the way history is taught in schools: "ces actions montrent à nouveau à quel point nos sociétés semblent avoir besoin de normes pour appréhender l'histoire, comme s'il fallait à tout prix résoudre aujourd'hui, et définitivement, toutes les incertitudes et contradictions d'hier" ["these actions show once again how much our societies seem to need standards to understand history, as if it was necessary at all costs to resolve today, and definitively, all the uncertainties and contradictions of yesterday"]. ${ }^{24}$

Other editorials noted that public memory on the Algerian War in France perpetually "oscillated between guilt and sadness" which finally left the public with a reductionist view of Algerian and French histories: "les Français ont une vision biaisée de l'Algérie d'avant 1962, qui oscille entre culpabilité et mélancolie. Les crimes du commandant Aussaresses d'un côté, le lamento des rapatriés de l'autre. Tortures et nostalgie. Forcément réductrice, cette vision de l'histoire n'aide pas à solder le passé" ["the French have a biased vision of Algeria before 1962, which oscillates between guilt and melancholy. The crimes of Commander Aussaresses on one side, the lamentation of the repatriated on the other. Tortures and nostalgia. Necessarily reductive, this vision of history does not help to settle the past"]. ${ }^{25}$

Conservative pieces on the "Aussaresses affair" in Le Figaro warned the public to temper its criticisms of the French military-with one editorialist arguing that although Aussaresses's actions are judged in the twenty-first century, the public should remember the difficult conditions of war: "L'armée a besoin également d'être écouté... Au manque de considération s'attachent aussi de difficiles conditions de vie et de travail" ["The army also needs to be listened to... The lack of consideration is also associated with difficult living and working conditions"]. ${ }^{26}$

More coverage on the Aussaresses affair in Le Figaro suggested that the general's revelations could enliven critical discussion about colonialism: "[Aussaresses] est personnellement responsable de ses actes. Mais il n'a fait qu'obéir aux ordres... Cet officier a raison de dire la vérité historique. Cela pourrait permettre d'écrire une histoire plus honnête de la colonisation" ["[Aussaresses] is personally responsible for his actions. But he only obeyed orders ... This officer is right to tell the historical truth. It could help to write a more honest history of colonization"]. ${ }^{27}$

For journalists like Beaugé, who initially interviewed Aussaresses, the motivation for providing the general a platform to speak was that his oral testimonials could add a new dimension to

\footnotetext{
24 "La guerre d'Algérie et la culture de la mémoire," Le Monde, April 5, 2002.

25 "La mémoire confisquée de l'Algérie française," Le Monde, March 4, 2003.

26 “Les armées ont le moral en berne," Le Figaro, May 8, 2001.

27 "Ne pas juger Aussaresses," Le Figaro, July 18, 2001.
} 
understandings of the Algerian War and French colonial history more broadly. In one editorial, Beaugé questioned if Aussaresses was attempting to relieve his conscience. In her view, Aussaresses was simply an old man who when presented with the opportunity to speak about his experiences did so. He was not a person asking "existential" questions or seeking to politically position himself in any way. ${ }^{28}$

Other journalists agreed with Beaugé's Aussaresses interviews arguing that France must look at and judge its "passé douloureux." 29 Public officials like President of the National Assembly, Raymond Forni, however, still adamantly opposed revisiting the past, stating: "Il est inutile d'attiser le feu...Une guerre n'est jamais propre...Il faut arreter de ressasser le passé. Nous devons tourner la page" ["It is useless to stoke the fire... A war is never clean... We must stop dwelling on the past. We must turn the page"]. ${ }^{30}$

Following Aussaresses's condemnations, media coverage on the Algerian War shifted to broader discussions about creating spaces for respectful dialogue and public commemoration projects concerning the war. On January 20, 2021, for instance, a "Memory and Truth Commission" was proposed by French historian Benjamin Stora in his final report to l'Elysée on French colonialism and Algeria. ${ }^{31}$ Stora specifically recommended that national narratives on the war acknowledge the murder of activists, such as Ali Boumendjel, under the orders of French generals, such as Aussaresses, as part of the international reconciliation process between France and Algeria. ${ }^{32}$

Reminiscent of the Truth and Reconciliation Commission (TRC) (1996-2003) in South Africa, led by Archbishop Desmond Tutu, following the fall of the apartheid regime - a France-Algeria "Memory and Truth Commission" would hold perpetrators accountable for violence and discriminatory policies enacted during the war. Furthermore, a "Memory and Truth Commission" might represent an initial step at shifting the narrative on French colonialism from disputes on archival representations of colonial pasts to acknowledgement of individual memories from marginalized communities and 'immigration cultures' still impacted by the legacies and traumas of the Algerian War in Europe and Africa.

\section{CONCLUSION}

Public history without individual memories or lived experiences of communities that have survived historical events can be viewed as inauthentic. It might even be called propaganda to present only state sanctioned accounts of historical events. Many governments will consequently enact laws to distinguish between what constitutes official national narrativesand what remains peripheral, or perhaps extremist individual, historical accounts.

In the aftermath of the Algerian War, the French government removed memories of the war from national speech, resulting in what historian John Talbott famously titled the "War Without a Name" (Talbott, 1981). Condemnation of Aussaresses through regulatory and punitive action

\footnotetext{
${ }^{28}$ Beaugé, "Le secret du général Aussaresses," Le Monde, May 19, 2001.

29 "La mémoire en face," Le Monde, January 1, 2002.

30 “Comment juger nos crimes en Algerie?" Le Monde, May 7, 2001.

31 "Report by Benjamin Stora (19 February 2021)," French Ministry of Foreign Affairs.

32 "France acknowledges murder of activist during Algerian War (2 March 2021)," French Embassy in London.
} 
uncovered public fears that he was acting as an apologist of torture, speaking on behalf of the French military, and reviving psychological traumas suffered during the war-with his final reprimand highlighting the significant impact that individual (affective) and emotional memories have on official laws, and public discourse.

The scandal surrounding Aussaresses further reinforced the idea that using lived experiences to discuss social, political, and moral injustices may have negative and positive effects. The media archives that circulated pertaining to the affair also showed that public censure is not necessarily public censorship - that freedom of speech would prevail - and that the press might perhaps be the greatest arbiter when faced with addressing social dilemmas and historical wrongs.

Towards a greater understanding of collective memory processes, the case of the Algerian War reveals the constant negotiations, formal networks and informal channels used to distinguish between legitimate and illegitimate sources of historical memory - and the consequences on culture, law, and society.

\section{CONFLICT OF INTEREST}

There are no conflicts of interests.

\section{FUNDING}

No funding was received to complete this research.

\section{REFERENCES}

\section{Articles}

Connolly, Paul, Smith, Alan and Kelly, Berni. (2002). Too Young to Notice? The Cultural and Political Awareness of 3-6 Year Olds in Northern Ireland. Northern Ireland Community Relations Council.

Dessí, Roberta. (2008). Collective Memory, Cultural Transmission, and Investments. American Economic

Review 98(1), 534-560. https://doi.org/10.1257/aer.98.1.534

Heffernan, Michael, and Heike, Jöns. (2012). Research Travel and Disciplinary Identities in the University

of Cambridge, 1885-1955. The British Journal for the History of Science 46(2), 255-286. https://doi.org/10.1017/s000708741200074x

Houllemare, Marie. (2018). Seeing the Empire Through Lists and Charts: French Colonial Records in the Eighteenth Century. Journal of Early Modern History 22, 371-391. https://doi.org/10.1163/15700658-12342603

Schwartz, Seth J., Jennifer B. Unger, Byron L. Zamboanga, and José Szapocznik. (2010). Rethinking the Concept of Acculturation: Implications for Theory and Research. American Psychologist 65(4), 237-251. https://doi.org/10.1037/a0019330

Shepard, Todd. (2015). 'Of Sovereignty': Disputed Archives, 'Wholly Modern’ Archives, and the PostDecolonization French and Algerian Republics, 1962-2012. The American Historical Review 120(3), 869-883. https://doi.org/10.1093/ahr/120.3.869

Stainforth, Elizabeth. (2017). From Museum to Memory Institution: The Politics of European Culture Online. Museum and Society 14(2), 323-337. https://doi.org/10.29311/mas.v14i2.646 
Tawil, Sobhi. "Final report of the meeting, Geneva, 15-16 May 1997," Graduate Institute of Development

Studies, University of Geneva.

\section{Books}

Alleg, Henri. (2006). The Question. UNP.

Assmann, Jan. (2008). Communicative and Cultural Memory, in An International and Interdisciplinary Handbook (eds. Astrid Erll and Ansgar Nunning).

Aussaresses, Paul. (2004). The Battle of the Casbah: Terrorism and Counterterrorism in Algeria, 19551957. Enigma Books.

Bourdieu, Pierre. (1984). Distinction: A Social Critique of the Judgement of Taste.

Fanon, Frantz. (1963). The Wretched of the Earth. Présence Africaine.

Horne, Alistair. (2006). A Savage War of Peace: Algeria, 1954-1962. New York Review of Books.

Jansen, Jan. (2010). Politics of Remembrance, Colonialism and the Algerian War of Independence in

France, in A European Memory? Contested Histories and Politics of Remembrance eds. Małgorzata Pakier and Bo Stråth. Berghahn Books.

Mccormack, Jo. (2006). Memory in History, Nation Building, and Identity, in Algeria and France, 18002000 Identity, Memory, Nostalgia, (ed. Patricia Lorcin). Syracuse University Press.

Mccormack, Jo. (2010). Collective Memory: France and the Algerian War (1954-1962). Lexington Books.

Talbott, John. (1981). The War Without a Name: France in Algeria, 1954-1962. Faber \& Faber.

\section{Newspaper and Media}

Abdelaziz Bouteflika a été inhumé à Alger, Emmanuel Macron salue une «figure majeure » de l'Algérie.

(September 19, 2021). Le Monde.

AHA Sends Letter to French President Emmanuel Macron with Concerns about Unclear Procedures for

Declassification of Archives. (Feb 2020). American Historical Association.

Beaugé, Florence. (November 23, 2000). Les aveux du général Aussaresses: 'Je me suis résolu à la torture.'

Le Monde.

Beaugé, Florence. (November 22, 2000). "Si la France reconnaissait et condamnait ces pratiques, je prendrais cela pour une avancée," Le Monde.

Beaugé, Florence. (November 23, 2000). Les aveux du général Aussaresses: 'Je me suis résolu à la torture.'

Le Monde.

Beaugé, Florence. (May 3, 2001). "L'accablante confession du général Aussaresses sur la torture en Algérie." Le Monde.

Beaugé, Florence. (May 19, 2001). Le secret du général Aussaresses. Le Monde.

Césaire, Aimé. (1978). Culture and Colonization. University of Yaoundé.

Chirac veut des sanctions contre Aussaresses. (May 5, 2001). Le Figaro.

Comment juger nos crimes en Algerie? (May 7, 2001). Le Monde.

Crimes contre l'humanité: le général Aussaresses ne sera pas poursuivi. (December 17, 2001). Le Monde.

Elgey, Georgette. (May 4, 2001). Crimes de la guerre d'Algérie: divulguer pour ne pas répéter. Le Monde.

France acknowledges murder of activist during Algerian War. (2 March 2021). French Embassy in London.

Général Paul Aussaresses 'les tortures en Algérie’ - Archive vidéo INA. Claude Serillon interview with 
Général Paul Aussaresses, former Intelligence Services Coordinator in Algiers in 1957. (November 23, 2000). Archives of INA Institut National de l'Audiovisuel.

La mémoire en face. (January 1, 2002). Le Monde.

La guerre d'Algérie et la culture de la mémoire. (April 5, 2002). Le Monde.

La mémoire confisquée de l'Algérie française. (March 4, 2003). Le Monde.

Les armées ont le moral en berne. (May 8, 2001). Le Figaro.

Letter to French President Jacques Chirac Calling for War Crimes Investigation. (May 13, 2001). Human

Rights Watch.

Ne pas juger Aussaresses. (July 18, 2001). Le Figaro.

Pas de commission d'enquête. (October 11, 2001). Le Figaro.

Report by Benjamin Stora. (19 February 2021). French Ministry of Foreign Affairs.

Torture en algerie. (May 4, 2001). Le Figaro. 